\title{
Base Erosion and Profit Shifting Case Studies to Examine Conflicting Views on Taxation
}

\author{
Hsiu-li Wu ${ }^{1,}$, , Shang-Yung Yen ${ }^{2}$ \\ ${ }^{1}$ Taxation and Accounting Group, College of Business, Feng Chia University, Taichung, Taiwan \\ ${ }^{2}$ Graduate Institute of Management of Technology, Feng Chia University, Taichung, Taiwan
}

Email address:

hsiuli.miss@msa.hinet.net (Hsiu-li Wu),syyen@fcu.edu.tw (Shang-Yung Yen)

${ }^{*}$ Corresponding author

\section{To cite this article:}

Hsiu-li Wu, Shang-Yung Yen. Base Erosion and Profit Shifting Case Studies to Examine Conflicting Views on Taxation. Journal of Finance and Accounting. Vol. 6, No. 5, 2018, pp. 117-126. doi: 10.11648/j.jfa.20180605.13

Received: October 21, 2018; Accepted: November 6, 2018; Published: November 30, 2018

\begin{abstract}
Multinational corporations have contributed to the unfair phenomenon of tax base erosion and profit shifting by taxation planning and transferring profits into countries or territories with low tax rates. The OECD, under the push from G20 member countries, launched 15 action plans for BEPS (Base Erosion and Profit Shifting), as an attempt to drive reforms in tax systems across different countries for a just and efficient taxation system. As part of this global initiative, the Taiwanese government is also amending its tax laws for better consistency, substance, transparency and fairness. This paper examines Google, Amazon and Starbucks headquartered in the U.S. and Feng Tay headquartered in Taiwan and analyzes how multinational corporations leverage the difference in tax rates in different countries and the existence of bilateral tax agreements for tax planning and profit shifting. The European Commission holds the view that such practices violate the laws of the European Union. This paper conducts an in-depth analysis on the arguments from both sides and develops suggestions on the basis of tax fairness, moral issues and research findings. It is hoped that taxations and profits travel in a just and efficient environment so that taxation fairness benefits economic developments and effective use of resources.
\end{abstract}

Keywords: Transfer Pricing, Intangible Assets, Base Erosion and Profit Shifting

\section{Introduction}

Taxes are an operating cost to corporates. It is a common practice that companies seek to reduce tax burdens to reduce tax expenses and boost profits by leveraging the different tax rates throughout the world. Tax planning for tax benefits typically involves the leverage of differences and information asymmetry in tax systems in different countries, via holding companies without comparable economic substances, and the legal engagements such as identity changes or transaction contracts. It is rather common for multinational enterprises (MNEs) to avoid taxes or to seek double non-taxation via tax arrangements to segregate profits and profit creating activities. This has caused taxation inequality [17]. As a response to the request from the Group of Twenty Finance Ministers and Central Bank Governors, the OECD issued on February 12, 2013 the report "Addressing Base Erosion and Profit Shifting" [12], as the foundation for the planning of a fair, objective and comprehensive tax base. [26]

The global competition has been intensifying among corporates and between countries. Hence, governments around the world are offering attractive tax incentives to lure multinational companies. The leverage of low tax rates or tax breaks offered by different countries by large corporates has led to base erosion and profit shift. As a disproportional amount of profits are retained in low-tax rate or even tax-free countries, it has resulted in unfairness in terms of tax revenues for other governments. The European Commission challenges the practice of profit retention via transfer pricing by multinational enterprises and suggests the determination of profit distributions on the basis of economic substance in relation to controlled transactions. The considerations include whether the rewards for intangible assets are in compliance with the OECD Transfer Pricing Guidelines [23], whether profits are enjoyed by the entities who make contributions to intangible assets and whether transfer pricing agreements violate the laws and regulations of the European Union. In 
conclusion, some multinational companies have to pay additional income taxes to countries such as the Netherland, Ireland and Luxembourg. However, all the governments are arguing in favor of corporates with the European Commission. This paper summarizes both sides of the story by conducting a few case studies, such as Google, Feng Tay, Starbucks and Amazon.

In order to stay in line with international taxation practice, the Ministry of Finance in Taiwan started its action plan on base erosion and profit shift in 2013. Up to the present, a few laws and regulations have been amended regarding cross-border e-commerce transactions and anti-thin-capitalization. The Taiwanese government has released Mutual Agreement Procedures and entered into comprehensive income tax agreements with a total of 32 countries. In addition, the laws on controlled foreign companies (CFCs) and places of effective management (PEMs) have been passed, and the principles for transfer pricing have been modified. Finally, the Taiwanese government also launched the Automatic Exchange of Information (AEOI) and other information sharing mechanisms, implemented the Common Reporting Standard (CRS) and promulgated the Regulations Governing Assessment of Profit-Seeking Enterprise Income Tax on Non-Arm's-Length Transfer Pricing[9]. These efforts aim to keep up with the international tax laws, contribute to the creation of tax justice and promote an effective utilization of resources for the global economy. [33]

\section{Theory of Optimal Tax Systems}

Globalization has intensified the competition for corporates. Governments around the world are offering tax incentives to attract investments from individuals and companies. However, tax benefits are also creating room for tax planning and imposing challenges for tax policies. It is imperative, therefore, for tax planners and policymakers to take into account the taxation principles, the theory of optimal tax systems and moral aspects to prevent tax revenue losses, in order to achieve the most appropriate allocations on the scale of tax justice.

\subsection{Canons of Taxation by Adam Smith}

Optimization of tax systems has been a topic of discussions by economic theorists and policymakers throughout the human history. Adam Smith in "The Wealth of Nations" published in 1902 propose four canons of taxations: equality, certainty, convenience and economy [26].

\subsubsection{Canon of Equality}

By equality Adam Smith means equality of sacrifice, i.e. each person paying taxes in proportion to incomes and within respective abilities, in order to contribute towards the support of the government.

\subsubsection{Canon of Certainty}

There should be certainty with regards to the amount which taxpayer is called upon to pay during the financial year, and this amount shall not be changed lightly. Adam Smith posits that tax rate uncertainty affects people more than tax injustice.

\subsubsection{Canon of Convenience}

The tax should be levied at the time and in the manner which is most convenient for the contributors.

\subsubsection{Canon of Economy}

The expenses incurred during the process of tax levying should be minimized so that the contributions from taxpayers are as close as the tax revenue to the government.

Tax payment is an obligation for citizens. Tax revenue allows a government to build infrastructure and offer social benefits to the disadvantaged groups. Tax payers care whether the tax is levied in a fair way and whether the tax revenue is used to help the public, rather than being embezzled by a small number of people or for the personal gains of a few individuals.

\subsection{Optimal Taxation Theory}

In 1927, the Cambridge-based economist Ramsey came up with the theory of optimal commodity sales taxes ${ }^{1}$. Ramsey holds that there is an inverse correlation between the optimal tax rate of a commodity and the demand elasticity for that commodity. Generally speaking, the demand elasticity of bare necessities in life is fairly low, but the demand elasticity for high-end products is high. The Ramsey rule dictates that efficient tax rates should be high on daily necessities and low on high-end commodities. Edgeworth posits the principle of vertical equity, i.e. when the marginal sacrifice is equal to every individual, the loss of social utility is minimized. This implies that the maximum marginal tax is $100 \%$. Once the income has reached a certain level, the earner will have to pay taxes for all the incremental incomes. As a result, high earners will reduce work hours and use the time to enjoy leisure activities. The tax revenue with the high tax rate is lower than that with the low tax rate due to foregone work hours and hence the loss of efficiency. Stern examines tax revenues and labor supply and concludes with a negative correlation between optimal income tax rates and labor supply elasticity. If the labor supply elasticity is low, the change of wage rates is less sensitive. A high tax rate does not affect labor supply policies, and hence it has a great impact on economic efficiency. On the other hand, if the labor supply elasticity is high, a high income tax rate will lead to a reduction in real wage rates, and an even greater reduction in labor supply. The Nobel laureate in economics James Mirrlees (1971) produces a classic analysis on optimal income taxes under incentives. With a set of stringent presumptions such as the distribution of labor capabilities, the maximization of government's gains, the maximization of labor utilization and no uncertainty, Mirrlees comes up with a series of remarkable findings. He argues that the marginal tax rate should be zero for the highest wage rate and the lowest wage rate.

1http://www.twword.com/wiki/ optimal taxation theory 
It explores whether there is a positive correlation between tax revenues[33] and an increase in tax rates in the context of optimal taxation theories. He believes that the endogenous variables regarding taxpayers, such as tax rates, penalty rates and audit rates, are contributing factors of the level of base erosion. If a government wishes to increase tax revenues with an income tax rate hike, it will cause greater base erosion and reduced tax revenues. If a change in tax rates is to serve as a tool to increase tax revenues and mitigate the uncertainty of tax revenue reductions as a result of base erosion, the government must seek to influence the base erosion in response to higher tax rates. For example, the government can enhance the moral guilt assumed by taxpayers who attempt to evade taxes. This should be accompanied with a tax environment of both horizonal equity and vertical equity. If a government fails to promote the moral ethics of taxpayers or control the base erosion created by tax evaders, simply changing tax rates, penalty rates and audit rates will not be an effective measure to reduce base erosion.

\subsection{Principle of Optimal Taxes}

The theories of optimal taxes and the distribution of tax revenues in the optimal tax system endeavor to achieve the highest level of social welfare. This begs the question on which principles and canons are in order to ensure tax fairness and justice. In addition to tax administrations and fiscal incomes, the contemporary principles of taxations focus on efficiency and fairness. As far as tax levy is concerned, tax incidence is for tax fairness $^{2}$ and excess burden is about tax efficiency. Tax incidence is the outcome of tax revenue distributions and redistributions. Richard Abel Musgrave [20] hold the view that it takes three steps from the levied tax to find its eventual incidence. These three steps are tax levy by the government, tax payments by corporates, transfers and incidence. The emphasis of tax incidence is on tax fairness and the effectiveness of tax revenue distributions. Tax levy on the basis of fairness and justice will enhance the willingness of taxpayers to hand over tax payments as they acknowledge the government's principles of tax collections and the utilization of tax revenues. Excess burden refers to the loss of monetary value for the additional burden assumed by taxpayers. If the monetary value of tax revenues falls below the monetary value resultant by the unpleasant feels of taxpayers when they pay taxes, the tax levy suffers a loss, known as excess burden or welfare cost. Optimal taxation is the taxation that minimizes excess burden. Of course, the administration costs in relation to the management and collection of minimized taxes is also an important consideration for tax efficiency. The economic efficiency of taxation is observed in the context of tax revenues and economic elements. It is about the effects of taxation on social resources and economic mechanisms as part of the workings of an economy [37].

\section{BEPS Action Plans and Case Studies}

The above literature view covers the canons of taxation by

2http://wiki.mbalib.com/zh-twtax incidence
Adam Smith, the theory of optimal taxes and the principle of optimal taxes. Today, multinational companies obtain tax gains and shift profits via cost reduction and profit enhancement by leveraging the variances and information asymmetry in tax rates and taxation systems in different countries. This runs in contrary with the tax fairness and efficiency principles advocated by scholars. In order to mitigate tax unfairness, the OECD initiated 15 BEPS (Base Erosion and Profit Shifting) Actions [32], [36], to prevent base erosion and avoid unfair profit distributions. These action plans aim to drive the global taxation environment towards substance, consistency and transparency. The table below summarizes the nature and classification of the BEPS 15 actions.

Table 1. Nature and Classification OECD BEPS15 Actions.

\begin{tabular}{lcc}
\hline Consistency & Substance & Transparency \\
\hline & (1) Treaty abuse (6) & (1) BEPS data \\
& (2) Permanent establishment & analysis (11) \\
(1) Hybrids (2) & status (7) & (2) Disclosure of \\
aggressive tax \\
(2) Interest deductions & (3) Transfer pricing: & planning (12) \\
(4) & intangible assets (8) & (3) Transfer pricing \\
(3) CFC rules (3) & (4) Transfer pricing: risk and & (3) \\
(4) Harmful tax & capital (9) & $\begin{array}{l}\text { documentation } \\
\text { practices (5) }\end{array}$ \\
& (5) Transfer pricing: & (13) \\
& high-risk transactions & (4) Dispute \\
& (10) & resolution (14) \\
Multilateral & Digital economy (1) & \\
instrument (15) & &
\end{tabular}

Source: Ho, Classification of OECD BEPS 15 Actions

\subsection{Law Amendments in Taiwan in Response to BEPS}

In 2013, the Ministry of Finance in Taiwan started its action plan on base erosion and profit shift. ${ }^{3} \mathrm{Up}$ to the present, a number of laws and regulations have been amended regarding cross-border e-commerce transactions and anti-thin-capitalization. The Taiwanese government has released Mutual Agreement Procedures and entered into comprehensive income tax agreements with a total of 32 countries. ${ }^{4}$ In addition, the laws on controlled foreign companies (CFCs) and places of effective management (PEMs) have been passed, and the principles for transfer pricing have been modified. Finally, the Taiwanese government also launched the Automatic Exchange of Information (AEOI) and other information sharing mechanisms, implemented the Common Reporting Standard (CRS).

\subsection{Law Amendments in Regard to CFC and PEM and a Case Study on Tax Avoidance by Google}

\subsubsection{Key Amendments on Laws Concerning CFC and PEM}

According to the current income tax laws, offshore

3The Ministry of Finance's eTax Portal, https://www.etax.nat.gov.tw: Income Tax Law, Alternative Minimum Tax, the Regulations Governing the Implementation of the Common Standard on Reporting and Due Diligence for Financial Institutions. 4Executive Yuan Gazette, 2017, 023 (171), Fiscal Policy and Economy: the draft for the Regulations for Tax Information Exchange under Tax Treaties. 
investees are only incorporated into the base for profit-seeking enterprise taxes in Taiwan when the retained earnings are distributed. Therefore, profit-seeking enterprises set up CFCs in low-tax territories (such as tax havens) and accumulate earnings in these offshore vehicles, in order to avoid the taxes that would have been payable if kept in Taiwan. Tax base in Taiwan is therefore eroded. Some companies with PEM establishment in Taiwan become foreign companies by setting up subsidiaries in low-tax territories (such as tax havens). Individuals assume the identity of non-residents to avoid the income taxes in and outside Taiwan. The income tax system is residence-based, i.e. residents liable for income taxes for domestic and overseas earnings. The establishment of foreign entities in tax exempt or low tax countries or the conversion into a non-resident identity to avoid income taxable payable by corporates and individuals violate the principle of fair taxation. Therefore, the amendment to the Income Tax Act passed its third reading by the Legislative Yuan in 2016 to construct a more robust legal framework to counter tax avoidance. $^{5}$

\subsubsection{Case Study: Tax Avoidance by Google}

Google has been engaged in tax avoidance by shifting profits among its headquarters in the City of Mountain View, California and offices in Ireland, Bermuda Islands, the Netherlands and Singapore. The Google headquarters sell its intangible assets, i.e. intellectual properties for the internally developed search engine and advertising services, at a low price to its shell company in Ireland. This is to reduce the tax burden on the U.S. headquarters and retain profits in Ireland where tax rates are low. The shell company in Ireland then charge royalties for the intangible assets at a high price to the operating entity in Ireland. However, if the operating entity in Ireland directly transfer profits to the shell vehicle in Ireland, it would have to pay income taxes to the Irish government. To avoid these tax expenses, Google set up another operating entity in Amsterdam, the Netherlands. As the tax code in the Netherlands defines the nationality of companies by the location of registration, rather than by the location of

5KPMG, 2016, BEPS and International Trends in Taxation.

Ernst \& Young Global Limited, 2017, Special Issue: BEPS and International Trends in Taxation.

PwC, 2017, BEPS and International Trends in Taxation.

PwC, 2017, the release by the Ministry of Finance of the draft for the Regulations Governing the Implementation of the Common Standard on Reporting and Due Diligence for Financial Institutions.

Deloitte Monthly, January, 2017, p.52-53.

Deloitte Monthly, 2017, July, p.9-10, p15-17, p25.

Deloitte \& Touche, 2016, Special Issue in August, An Analysis on Counter Measures for Tax Avoidance and New Perspectives of Tax Management in the Post-BEPS Era).

Deloitte \& Touche, 2016, Kuo, Y. P., Li, C. W. Impact of Global Taxation Information Exchange on Financial Institutions in Taiwan.

Accounting Research Monthly, 2013, (337), Liao, L. L., Fan, H. C. In the Wake of BEPS Actions - Transfer Pricing Documentation and Memorandum for Country-by-Country Reporting.

Accounting Research Monthly, 2015, (357), Chou, C. P., Lin, C. J., Tsai, H. C., Chen, I. F. Most Recent Developments on BEPS - Assessment of Risks and Intangible Assets. headquarters, the income taxes are exempt for all the transactions between member states in the European Union. Finally, Google shifts profits via transfer pricing to the entity in Bermuda Ireland. Throughout the chain of the tax avoidance activities, Google is subject only to a low tax rate and base in the Netherlands and a portion of income taxes in Ireland. As a result, two thirds of its pre-tax earnings are in overseas accounts. As long as these profits are not repatriated back to the U.S., they will not be subject to taxes in the U.S. Meanwhile, Google also transfers part of the intellectual properties in Ireland via Amsterdam to Singapore. (This should be moved up as part of the chain of tax avoidance exercises).

This is how Google uses the legal setup at its headquarters in the City of Mountain View, California (with a tax rate of $35 \%$ ), Ireland (12.5\% the tax rate), Bermuda Ireland (tax free), the Netherlands (20\% tax rate) and Singapore (17\% tax rate) to avoid taxes and save a few hundred million of U.S. dollars each year [29]. The institution of two entities in Ireland is the so-called "Double Irish arrangement".

According to the documents presented by Google in 2015 to the Netherlands Chamber of Commerce, the capital transferred from Google Netherlands Holdings BV to Bermuda increased by $40 \%$ compared to 2014 . Meanwhile, the disclosure from Alphabet, the parent company of Google, to the U.S. Securities and Exchange Commission suggests that Google's aggregate profits overseas rose to USD 58.3 billion in 2015, with the majority transferred to the shell company in Bermuda. The file archive maintained by the Dutch government indicates that Google transferred EUR 14.9 billion (or USD 15.5 billion) profits to the shell company in Bermuda in 2015 to avoid taxes totaling USD 3.6 billion. The effective tax rate paid by Google in 2015 outside the U.S. was reduced to $6.4 \%$.

The entities in Ireland, the Netherlands and Singapore are CFCs under Google's headquarters in the U.S, and the entity in Bermuda is the PEM establishment for the U.S. headquarters. Pursuant to the BEPS Action 3 on CFC and the Action 7 on PEM, foreign investment incomes should be counted into the taxable incomes of the parent company during the same year. The BEPS Actions 8 to 10 prescribe the regulations governing beneficial owners for transfer pricing of intangible assets. The BEPS Action 13 Transfer Pricing Documentation and Country-by-Country Reporting details the three-tier structure of documentation, i.e. a master file, country-by-country reports and a local file containing information for each country. The BEPS Actions 11 to 14 on transparency propose the Automatic Exchange of Information (AEOI) and other information sharing mechanisms and Common Reporting Standard (CRS). These measures will penalize Google's U.S. headquarters for its tax avoidance and demand Google to pay extra in back taxes for previous earnings to the European Union.

\subsection{Back Taxes Payable After Amendment to Transfer Pricing Laws: Feng Tay Enterprise as an Example}

The OECD's BESP Action 13Transfer Pricing 
Documentation and Country-by-Country Reporting, released on September 16, 2014 specifies the three-tier approach to documentation, i.e. a master file, country-by-country reports and a local file containing information for each country. To keep in line with international practices and comply with the guiding principles for transfer pricing, the Regulations Governing Assessment of Profit-Seeking Enterprise Income Tax on Non-Arm's-Length Transfer Pricing in Taiwan stipulate that taxpayers shall prepare the master files, country-by-country reports and local files for information in each country. In addition, companies with consolidated revenues above EUR 750 million (approximately NTD 27 billion) during the previous year are required to disclose the allocation of their global value chains, incomes and tax information ${ }^{6}$.

\subsection{Definition and Working of Transfer Pricing}

Transfer pricing is a means for multinational corporations to maximize profits and achieve global targets by manipulating the prices of tangible and intangible assets in different countries and jurisdictions [17] indicates that technology licensing, patents and knowhow are priced based on use. The interest rate base affects profitability if interest expenses are to replace dividends. Leasing is another profitability factor, as it reduces the financial burden of upfront capital expenditures and boosts bottom line by hiking up leasing expenses. Multinational enterprises use the subsidiaries in countries where tax rates are low for procurements at below market prices and selling at above market prices. The parent companies located in countries where tax rates are high purchase at above market prices and sell at below market prices, so that high cost of goods sold and low revenues squeeze profits in the high tax rate countries. This is essentially transferring profits from the parent companies in high tax rate countries to the subsidiaries in low tax rate countries and as a result, alleviates the overall tax burden of the business.

As far as the pricing of intangible assets is concerned, the OECD contends that the transfer of intangible assets should not be confined to either accounting or legal definitions. Rather, it is the economic substance that counts. In other words, intangible assets are more than just non-tangible assets or financial assets. It is about whether the intangible assets can be owned or controlled in the business activities and whether the intangible assets generate significant economic benefits. The OECD discussions state that intangible assets should meet the following three criteria: (1) non-physical or non-financial assets; (2) ownership or control possible when used in business activities; (3) a price to be paid for the use or transfer of such assets in arm's length transactions. On September 16, 2014, the OECD published the Guidance on Transfer Pricing Aspects of Intangibles to reiterate that it is necessary to take into account the

6 Ministry of Finance, 2015, Regulations Governing Assessment of Profit-Seeking Enterprise Income Tax on Non-Arm's-Length Transfer Pricing, Ministry of Finance's official website contributions from the legal ownership, development, enhancement, maintenance, protection and exploitation (DEMPE) of intangible assets. Whilst the legal owners of intangible assets are rewarded for the development or transfer of such intangible assets, other participants in the multinational groups are also entitled to compensations in arm's length transactions for their contribution to the asset value by performing functions, utilizing or contributing assets or assuming risks. It is necessary to determine the contributions to the value of intangible assets and corresponding allocations of earnings for companies and affiliates and decide on the reasonable prices for intangible assets. Given the unique nature of intangible assets, the OECD has developed valuation techniques if no data is available for comparatives. These techniques involve price estimates based on relevant financials, such as discounted cash flows.

\subsection{Case Study: Feng Tay Enterprise}

Founded in 1971, Feng Tay began in 1977 to produce sports shoes for Nike, an international brand. In response to Nike's global procurement strategy, Feng Tay started to set up manufacturing facilities in China, Indonesia, Vietnam and India. In 1992, the company worked with Nike to established Nike's first joint Asian venture R\&D center in Taiwan. Since 2013, the Fujian Local Taxation Bureau started to examine the transfer pricing as far back as in 2006 by Xie Feng and San Feng, two of Feng Tay's companies. At the end of 2016, the Fujian Local Taxation Bureau determined that Feng Tay avoided taxes with transfer pricing and demanded the company to pay RMB 222 million (or NTD 1 billion) plus interests in back taxes. The Fujian Local Taxation Bureau pointed out that Feng Tay's shoe manufacturing activities are in Fujian, but received customer orders via its subsidiary in Bermuda, Growth-Link Overseas, and then placed orders to its subsidies in Fujian, Xie Feng and San Feng. The Fujian Local Taxation Bureau argued that customer orders should have been placed with the subsidiaries in Fujian where the shoe manufacturing facilities are located, and the subsidiaries in Fujian would pay technical service fees to the headquarters in Taiwan and administrative fees to Growth-Link Overseas. According to the adjustment made by the Fujian Local Taxation Bureau, Xie Feng should pay business income taxes RMB 77.584 million in back taxes and the corresponding value-added taxes of RMB 28.31 million. In addition, Feng Tay should pay additional income taxes at RMB 28.665 for the technical service fees to Taiwan. In aggregate, a total of RMB 134 million back tax payments are in order. In addition, San Feng should hand in business income taxes RMB 46.026 million in back taxes and the corresponding value-added taxes of RMB 20.313 million. This combined with the income taxes payable by Feng Tay for its technical services to Taiwan at RMB 21.921 means that a total late tax bill of RMB 88.26 [3].

Feng Tay states that the headquarters in Taiwan are responsible for $R \& D$ and product design. Growth-Link 
Overseas receives customer orders. It is justified that technical service fees are assumed in Taiwan and manufacturing costs are incurred in China. Before the establishment of trade links between China and Taiwan, Taiwanese companies could only invest in China through vehicles in other territories. Many listed companies or small-and-medium enterprises set up vehicles in tax havens in order to invest in China. Feng Tay's subsidiary, Growth-Link Overseas, was created in those times when no formal trade links were in place between China and Taiwan. It has been a long-standing and legal business practice for Taiwanese enterprises operating in China. Feng Tay made its declaration of objection to the Fujian Local Taxation Bureau but both parties could not find any common grounds in the definition of "ownership". Chairman Chiu-Hsiung Wang stated that Feng Tay always adheres to local laws and regulations in China and does not evade or avoid taxes. In other words, Feng Tay does not bulge on its ownership of orders. The center of this argument is the entity that owns and receives client orders, i.e. whether any manipulation and transfer of intangible assets is involved. Chiu-hsiung Wang said that if the tax authorities cannot understand and insist on the tax levy, the company will pay, at the price of moving out of China immediately. Feng Tay said that the company always acts with honesty and integrity, and observes local laws and regulations. Objections have been made to the Fujian Local Taxation Bureau and relevant administrative and legal procedures have been on-going. Management will also make appropriate actions in response to how the matter affects its financials.

This paper summarizes the contentions between both parties. Firstly, it is about the definition of transfer pricing. The Fujian Local Taxation Bureau refers to the OECD's definition of intangible assets. In this context, Feng Tay's headquarters in Taiwan receives certain rewards as the legal owner of intangible assets for the development or transfer of such assets. However, the participating entities in Fujian, China also deserves rewards throughout arm's length transactions, given their contribution to the value of these assets by performing functions, using or contributing to the assets or assuming risks. Second, it is about the difference in the definition of operating entities. According to the BEPS Action 3 on CFC and Action 7 on PEM, Feng Tay shall include the incomes in the Bermuda subsidiary into the income taxable base and VAT taxable base for the entity in Fujian, China. Over recent years, the Chinese government has been investigating on tax avoidance by multinational companies via transfer pricing. After the promulgation of the Public Notice on Matters Regarding Refining the Filing of Related Party Transactions and Administration of Contemporaneous Transfer Pricing Documentation (Public Notice of the State Administration of Taxation [2016] 42), the State Administration of Taxation collected a total of RMB 23.9 billion of back tax payments for 2011, and the amount increased to RMB 61 billion for 2015. In aggregate, the tax authorities in China chased RMB 218.7 in back taxes for the five-year period from 2011 to 2015. In sum, the Chinese government has significantly increased its tax revenue by implementing the BEPS Action 8 to Action 10 on transfer pricing of intangibles and Action 7 on PEM.

\subsection{Case Study: Amazon.com Inc.}

The U.S. mega e-commerce company Amazon.com Inc. was demanded by the European Union on October 4, 2017 to pay EUR 250 million (approximately NTD 9 billion) in back taxes. Amazon.com Inc. stated that the holding company in Luxembourg is its European headquarters and charges patent fees from affiliates. However, the European Commission pointed out that the holding company in Luxembourg has no employees, no offices, no business activities and hence, is not a PEM. The investigations by the European Union found the patent fees charged by the holding company in Luxembourg were not in compliance with transfer pricing rules or arm's length transaction practices, and the prices were above market prices. In the meantime, the taxation agreement reached by the Luxembourg government and Amazon.com Inc. in 2003 was an improper taxation subsidy, as Amazon's holding company in Luxembourg did not pay taxes for nearly $75 \%$ of its profits. In conclusion, the European Commission accused the Luxembourg government for its unfair practice as other companies did not receive the same tax incentives and hence fair competition was comprised.

Amazon's spokesperson responded by saying that Amazon owns certain intellectual properties conducive to industrial developments and entitled to tax breaks and such intellectual properties are owned by its holding company in Luxembourg. The Luxembourg government stated that the tax incentives offered to Amazon were completely legal in the context of the laws at that time, and Amazon paid taxes according to international laws and the laws of Luxembourg. Therefore, the Luxembourg government objected to the decision by the European Union as all the tax system in Luxembourg is in compliance with the laws of the European Union. In a nutshell, the Luxembourg government stands by Amazon in this taxation dispute against the European Union. Luxembourg attracts multinational companies to set up their European headquarters within the border of Luxembourg by offering tax rates lower than those in other member states of the European Union [25].

This paper wonders whether the royalties charged by the owner of intangible assets, i.e. Amazon's holding company in Luxembourg are appropriate on the basis of the holding company's contributions and risk undertakings for such intangible assets. The BEPS Actions 8 to 10 stipulate that the providing of capital does not equate to the ownership of the value and rewards of intangibles. The providing of capital only and without the capability in management and control of financial risks is only entitled to a reward equivalent to risk-free interest rates. To validate whether the transactions of intangible assets between affiliates are in arm's length, the OECD came up with the DEMPE approach, i.e. the contribution to the development, enhancement, maintenance, protection and exploitation of intangible assets, as the framework for the analysis of asset utilization and risk 
undertaking for the assets. If an owner of intangible assets is not involved in the DEMPE activities or assumes relevant risks, it does not deserve the profits created by such intangible assets. In other words, the analysis of transfer pricing should be based on economic substance and the functions and risks assumed by different participants. Contractual regulations and legal ownerships are not the only basis for the rewards associated with intangible assets entitled by owners.

In conclusion, the ownership of intangible assets without contribution to the value of intangible assets does not deserve the distribution of earnings created by intangible assets. This begs the question whether the transfer pricing transactions with Amazon's holding company in Luxembourg are accompanied with real functions or are conducted simply via legal or contractual forms. In fact, the holding company has no employees, no offices and no commercial activities. According to the BEPS Action 7 on PEM, domestic and overseas incomes shall be included into the taxable incomes even if the domestic companies become foreign companies by registering in low tax-rate territories. Finally, the Luxembourg government entered into a taxation agreement with Amazon in 2003 whilst the OECD released the BEPS directives on February 12, 2013 in response to the request from G20 member states. Obviously, the tax agreement between the Luxembourg government and Amazon's holding company in Luxembourg was in line with international practices and the tax treaties Luxembourg had at that time, before the OECD's publication of the 15 BEPS Actions. As laws are not retroactive, the debate between the European Union as one party and the Luxembourg government and Amazon as the other party is likely to drag for a long time.

\subsection{Case Study: Starbucks}

Starbucks established its EMEA (Europe, Middle East and Africa) headquarters in Amsterdam, the Netherlands in 2014 for day-to-day management, the trading of coffee beans and the roasting of coffee beans. The EMEA headquarters sell the technology of green beans roasting to the Starbucks coffee shops in the region and recognizes profits, costs and expenses associated with the EMEA operations. In the case the European Union vs. Starbucks, Starbucks' EMEA headquarters pay the royalties for the use of trademarks and the knowhow for coffee beans roasting and coffee making to Alki, Starbucks' affiliate in the U.K. and purchases green beans from a Swiss company. The European Union contends that Starbucks retains profits in its entity in the Netherlands via transfer pricing to avoid taxes.

Starbucks argues that its EMEA headquarters pay the royalties to Alki, its affiliate in the U.K. for the use of trademarks and the knowhow for coffee beans roasting and coffee making and procures green beans from its Swiss company. Both expenses are recognized according to the Advanced Pricing Agreement (APA) with the Dutch tax authorities. The anti-BEPS guidelines published by the OECD provide a number of indicators for transfer pricing.
One is the so-called Transactional Net Margin Method. In 2008, Starbucks reached APA with the Dutch tax authorities, and this provided advanced certainty to Starbucks and served as the basis for the Dutch government's review of the transfer pricing data submitted by Starbucks. This ten-year agreement was valid from October 2007 through December 2017. According to the report issued by the European Union, Starbucks provided transfer pricing methods to the Dutch tax authorities. The reviewers in the Dutch tax authorities believed that the transfer pricing methods used by Starbucks meet the OECD criteria. In a nutshell, both parties have reached consensus on fee calculation methods.

The Dutch government argued that its tax authorities have incorporated the OECD guidelines into its domestic laws and regulations. The agreement with Starbucks was based on these laws and agreements and this type of tax agreements can happen with any other company. The Dutch government does not favor multinational companies. It is the government 's responsibility to ensure that companies understand the tax codes and policies in the Netherlands by providing relevant details and advanced certainty. This serves as a foundation for the compliance by multinational companies. In its response to the European Union, the Dutch cabinet contended that it is necessary to help the European Union to resolve taxation problems but at the same time maintains an attractive business environment for companies from other countries.

This paper believes that the core of the debate between Starbucks and European Union lies in whether goodwill as an intangible asset can be included into transfer pricing. First, let us start with the location of value creation and the basis of net incomes. Starbucks' U.K. headquarters contribute to earnings by investing heavily in design, R\&D and marketing. However, there are no open market for the royalties of coffee coasting knowhow. Every coffee shop can claim its ability to create unique coffee aromas, and demand handsome licensing fees accordingly. Net incomes are incurred in Europe, where the EMEA headquarters recognize revenues, costs and expenses. Whilst the U.K. headquarters contribute to design, $R \& D$ and marketing, the expenses are reported by the EMEA headquarters and hence, net incomes are relatively low ${ }^{7}$. In a message on Apple's community, Apple's CEO Tim Cook said that profits should be taxed according to the location of value creation, not the location of net incomes reporting.

As previously mentioned, multinational enterprises are able to transfer the ownership of intangible assets, in legal terms or contractual forms, to the entities domiciled in countries offering tax incentives or low tax rates. For example, intangible assets attract royalty incomes from other affiliates so as to reduce the effective tax rate for the group. The BEPS Actions 8 to 10 endeavor to align transfer pricing outcomes with value creation, and delves into the issues of transfer pricing for intangible assets. One of the purposes is to prevent unreasonable arrangements (e.g. legal ownership

7http://losimprevisibles.blogspot.com/2016/09/blog-post_20.html 
of intangible assets and licensing of intangible assets) from transferring profits to entities located in low tax-rate countries. The profits generated by intangible assets should belong to the parties contributing to such value. Funding alone does not equate to the ownership of value and rewards of intangible assets. Without the capability in management and financial risk control, the provider of capital is only entitled to a return equivalent to risk-free interest rates. However, the OECD's anti-BEPS guidelines do not impose rigid requirements on the rewards corresponding to DEMPE activities. Rather, the emphasis is on the monitoring and control of the DEMPE functions and the determination of appropriate rewards according. The nucleus of the debate between the European Union and Starbucks is whether Starbucks aligns the allocation and value creation of intangible assets and provides transparent information in compliance with the OECD BEPS Actions 8 to 10 .

Finally, the contributions generated by goodwill are also part of the debate. Intangible assets can be largely divided into two categories. The first category is registered patents, trademarks and copyrights. This type of intangible assets is protected by laws and highly identifiable. The second category of intangible assets is less easy to identify. Such intangibles serve as value drivers for corporates, and are clubbed together as goodwill in accounting terms. The licensing of coffee roasting knowhow and the value drivers of goodwill as intangible assets create the multiplying effects and achieve high profits for Starbucks' U.K. headquarters. In addition to APA and advanced certainty granted to Starbucks, the European Union did not take into account the value of goodwill.

The companies examined by this paper, Google and Amazon, as well as Apple, reiterate that tax levy is on where value is created, not where net income is reported. The location of value creation is implied in the company's goodwill.

\section{Scale of Corporate Competition and Tax Fairness}

Chapter 3 of this paper conducts case studies and analyzes the tax disputes between European Union and companies concerned. (National governments are in favor of Silicon Valley giants as described above). The source of such disputes is the hunt by multinational companies for low tax rates, tax incentives, encompassing tax agreements for intangible assets in different jurisdictions. This on-going tax war between the European Union on one side and national sovereignties and multinational enterprises on the other is unlikely to be resolved anytime soon. According to Gillian Brock and Thomas Pogge [2], tax inequality is a global issue, with strong nations offering unfair tax subsidies to undermine the competitiveness and economic development of weak countries, who are usually lacking in professional expertise, comparable administrative capability or political influence. As a result, the abuse of tax incentives by multinational companies cannot be effectively mitigated. Base erosion caused by tax avoidance of multinational enterprises should be a key issue for all the justice theorists around the world. Tax avoidance creates negative effects on corporate images, social justice and moral perspectives. Whilst it is not illegal, it is unfair. It deepens the divide between the rich and the poor and violates the principles of tax fairness and tax efficiency. Companies should be run by national elites, to cumulate wealth for the firms and the countries by driving economic developments. Peter Dietsch and Thomas Rixen [8] examine the appropriate purposes served by tax revenues and conclude that an unfair and radical world may emerge as a result of corporate competition. They suggest governments and authorities to intervene in order to support fair redistributions of tax revenues and indirectly alleviate the global phenomenon of tax unfairness.

Chapter 2 elaborates on taxation principles. In addition to tax administration and fiscal incomes, tax levy should be based on the principles of fairness and efficiency. Shifting of taxation, such as tax levy by governments, tax payments by companies, shifting of tax incidence are all ways to achieve tax fairness, efficiency and optimal taxation. Economists seek to provide guidance on tax fairness and efficiency by proposing optimal tax systems. The purpose is to enable the best use of resources and economics via tax incidence and tax distributions, so that both governments and taxpayers can work together to spend tax revenues in a near-perfect tax environment. The competition between nations is so fierce today virtually all governments are offering tax incentives, tax agreements and subsidies to attract multinational corporates. For instance, France, Germany and the Netherlands offer varying levels of subsidies to domestic agriculture. In Taiwan, agricultural produce is tax free. Telecom operators around the world are often beneficiaries of government subsidies. High-tech companies in China and South Korea receive government sponsorships. In 2017, the U.S. President Trump lowered business income taxes and provided tax incentives to attract investments from large companies, create jobs and boost economic growth in the U.S.

To pursue survival and achieve profit maximization, companies take advantage of government subsidies and tax agreements in different countries. This has resulted in the phenomenon that domestic tax burdens are always higher than in overseas, and the difference is part of the competition between companies. The concept of a single market is to ensure fair competition for companies of different nationalities, but subsidies comprise tax fairness. That said, legal resolutions are unlikely to be reached anytime soon for the companies leveraging complex taxation policies amid the labyrinth of legal machines, within and across borders.

\section{Conclusion and Suggestions}

This paper employs the inductive method in the analysis of how multinational companies utilize tax incentives in different countries to reduce tax burdens. For example, Apple 
and Google set up subsidiaries (CFCs) and offices (PEMs) in low tax-rate countries such as the Netherlands, Ireland and Bermuda and maximize post-tax earnings with transfer pricing for intangible assets. The leverage of tax incentives by multinational companies and citizens with multiple nationalities in different countries has maximized the wealth of these companies and high net worth individuals, with minimum contributions to tax revenues, social and economic development. These seemingly legal but unfair tax practices have been an impeding factor to the economic development of impoverished, undeveloped and developing countries. Economists hold the view that domestic tax policies may distort the allocation of domestic resources. It is hardly surprising that national taxation policies will distort the allocation of global resources against the backdrop of economic globalization. This creates a dead loss to the world's economy. This paper contends that tax avoidance is detrimental to the economic development of developing countries, as well as to corporate images, social justice and morality. The causes of unfair taxation around the world are summarized in this paper. For example, the value transfer of intangible assets should take into the consideration for the difference in the basis of value creation and the location of net incomes incurred. The distribution of profits should be based on the economic substance of the controlled transactions. The rewards for intangible assets should be in conformity with the OECD 's guidelines for transfer pricing. In principle, profits should be attributable to the entities who contribute to the development, maintenance, protection and utilization of intangible assets, not necessarily to the legal owners of intangible assets. At last but not the least, the agreements for transfer pricing and safe harbors should be placed under scrutiny.

To curb tax unfairness, this paper proposes the following measures to improve the taxation environment:

(1) Establishment of tax fairness organizations to harmonize the differences in taxations, definitions and practices;

(2) Redefinition of international tax standards, legal frameworks and policies;

(3) Appropriate oversight and information exchange to promote transparency;

(4) Formation of optimal tax rates and improvement of taxation governance;

(5) Legal restrictions on the authorization of political agents and innovative approaches to abuse the system;

(6) Acceleration of cooperation between multilateral stakeholders and joint efforts in tax agreement issues;

(7) Sharing of financial information among tax authorities in different countries;

(8) Step-up of international aides to help the countries with tax problems;

(9) Training of personnel to provide legal and taxation assistance;

(10)Reinforcement of corporate government across the board;

(11)Promotion of international politics to encourage distribution justice and social ethics;

(12)Limitation of the use of tax havens and allowing international organizations to recoup lost and back taxes;

(13)Enhancement of moral standards for taxpayers.

\section{References}

[1] Apple Statement (2017). The facts about Apple's tax payments.

[2] Brock, G. and Pogge, T. (2014). Global Tax Justice and Global Justice MOPP, 1-15.

[3] China Times (2016). Feng Tay Investigated by Chinese Government for Back Taxes. Deloitte Monthly, January, 2017, 52-53.

[4] Chou, C. P., Lin, C. J., Tsai, H. C., and Chen, I. F., (2015). Most Recent Developments on BEPS - Assessment of Risks and Intangible Assets. Accounting Research Monthly, (357).

[5] Deloitte Dbriefs Special (2015), OECD Transfer Pricing Guidelines: Nearing the Finish Line.

[6] Deloitte Monthly (2017), July 2017, 9-10, 15-17, 25.

[7] Deloitte \& Touche (2016). Special Issue in August, An Analysis on Counter Measures for Tax Avoidance and New Perspectives of Tax Management in the Post-BEPS Era).

[8] Dietsch, P. and Rixen, T. (2014). Redistribution, Globalisation, and Multi-Level Governance, 1-28.

[9] Executive Yuan Gazette (2017). Fiscal Policy and Economy: the draft for the Regulations for Tax Information Exchange under Tax Treaties, 023 (171).

[10] Ernst \& Young Global Limited (2017). Special Issue: BEPS and International Trends in Taxation. Fair Competition? Tax Fairness? What is the European Union after? See http://losimprevisibles.blogspot.com/2016/09/blog-post_20.h tml, last visit at 20 September 2018.

[11] Heady, C. (1993). Optimal Taxation as a Guide to Tax Policy: A Survey Fiscal Studies, 15-41.

[12] Hou, H. C. (2017). OECD and Korea Policy Center, Seminar on Minimum BEPS Standards.

[13] Jeremy Kahn and Martijn Van Der Starre (2016). Bloomberg.

[14] Kuo, Y. P. and Li, C. W. (2016). Impact of Global Taxation Information Exchange on Financial Institutions in Taiwan. Deloitte \& Touche.

[15] KPMG (2016). BEPS and International Trends in Taxation.

[16] Liao, L. L. and Fan, H. C. (2013). In the Wake of BEPS Actions - Transfer Pricing Documentation and Memorandum for Country-by-Country Reporting. Accounting Research Monthly (337).

[17] Liu, T. T. (2008). International Tax Planning, Great Books.

[18] Meeting of the OECD Council at Ministerial Level Paris (2014). 
[19] Ministry of Finance (2015), Amendment to the Regulations Governing Assessment of Profit-Seeking Enterprise Income Tax on Non-Arm's-Length Transfer Pricing, Ministry of Finance's official website.

[20] Musgrave, R. A. (1959). Principles of Finance. PwC, 2017, BEPS and International Trends in Taxation.

[21] OECD Country-by-Country Reporting (2017). Handbook on Effective Tax Risk Assessment.

[22] OECD Transfer Pricing Report (2015). News Archive.

[23] OECD (2017). Transfer Pricing Guidelines for Multinational Enterprises and Tax Administrations.

[24] PwC (2017). The release by the Ministry of Finance of the draft for the Regulations Governing the Implementation of the Common Standard on Reporting and Due Diligence for Financial Institutions.

[25] Sing Tao Daily (2017). European Union Demands \$300 Million in Back Taxes from Amazon.

[26] Smith, A. (1902). The Wealth of Nations, Scotland, W. Strahan and T. Cadell, London, Nanyang College 1902 Chinese, Canons of Taxation.

[27] Tax theory. See http://www.twword.com/wiki/optimal, last visit at 20 September 2018.

[28] Tax incidence. See http://wiki.mbalib.com/zh-, last visit at 20 September 2018.
[29] Technews (2016). Tax Avoidance Planning by Google.

[30] The Ministry of Finance's eTax Portal, Income Tax Law, Alternative Minimum Tax, the Regulations Governing the Implementation of the Common Standard on Reporting and Due Diligence for Financial Institutions. See https://www.etax.nat.gov.tw, last visit at 20 September 2018.

[31] Tsilly, D. (2017). International Tax and Global Justice, T Dagan - Theoretical Inquiries in Law, 2017 - degruyter.com, $1-36$.

[32] Wang, L. M. (2015). Tax Agreements and Relevant Issues, Joint Seminar on BESP by OECD and Inland Revenue Board of Malaysia.

[33] Wang, Y. K. (2017). The Economic Analyses of Tax Evasion Based on the Browning and A-S Models. Asia-Pacific Economic and Management Review, 20(2), 53-72.

[34] Yang, S. C. (2016). Anti-Tax-Avoidance Clauses in Taiwan Income Tax Act §43-3 (CFC) and §43-4(PEM), Impacts and Responses (I).

[35] Yang, S. C. (2016). Anti-Tax-Avoidance Clauses in Taiwan Income Tax Act §43-3 (CFC) and §43-4(PEM), Impacts and Responses (II).

[36] Yu, I. T. (2017) Taipei Economic Inquiry, (17), Adjustment of Taxation Policies in Taiwan in the Context of the OECD's Anti-BEPS Guidelines.

[37] Yue, S. (2008). Public Finance and Taxation, Tsinghua University Press. 